\title{
Convective, intrusive geothermal plays: what about tectonics?
}

\author{
A. Santilano, A. Manzella, G. Gianelli, A. Donato, G. Gola, I. Nardini, E. Trumpy, and S. Botteghi \\ National Research Council, Institute for Geosciences and Earth Resources, Pisa, Italy \\ Correspondence to: A. Santilano (alessandro.santilano@igg.cnr.it)
}

Received: 26 June 2014 - Revised: 27 June 2015 - Accepted: 26 August 2015 - Published: 15 September 2015

\begin{abstract}
We revised the concept of convective, intrusive geothermal plays, considering that the tectonic setting is not, in our opinion, a discriminant parameter suitable for a classification. We analysed and compared four case studies: (i) Larderello (Italy), (ii) Mt Amiata (Italy), (iii) The Geysers (USA) and (iv) Kizildere (Turkey). The tectonic settings of these geothermal systems are different and a matter of debate, so it is hard to use this parameter, and the results of classification are ambiguous. We suggest a classification based on the age and nature of the heat source and the related hydrothermal circulation. Finally we propose to distinguish the convective geothermal plays as volcanic, young intrusive and amagmatic.
\end{abstract}

\section{Introduction}

Geothermal energy is a renewable resource suitable for baseload power production. Various countries are working toward an increase of geothermal exploitation and research development. Although geothermal energy has been exploited for many decades in many countries, a clear and unique classification of geothermal systems has not been accepted worldwide, probably due to the strong variability of geological, geophysical and thermodynamic conditions. In the past, many authors proposed a classification of geothermal systems and resources, based mainly on temperature (e.g. Muffler, 1979; Sanyal et al., 2005). Recently Moeck et al. (2014) proposed an alternative scheme to classify geothermal systems, in the frame of "geothermal plays", based on geological characteristics. The "play" concept hails from oil and gas exploration and corresponds to a "... model in the mind of the geologist of how a number of geological factors might combine to produce petroleum accumulation in a specific stratigraphic level of a basin" (Allen P. A. and Allen J. R., 2005). It is hard to import this concept to geothermal exploration due to the possible development of geothermal systems in many geodynamic settings with extremely various geological characteristics worldwide. On the other hand, we agree with Moeck (2014) on the need for a clear and widely accepted new catalogue of geothermal plays to support geothermal exploration activities at least in their very first activities. By merging different opinions and scientific discussions during a recent workshop held by the International Geothermal Association (IGA) in Essen, Germany (IGA, 2013), classification of the geothermal plays has been attempted as follows:

1. convective, volcanic field, divergent margins;

2. convective, volcanic field, convergent margins;

3. convective, intrusive, extensional;

4. convective, intrusive, convergent;

5. convective, extensional domains fault controlled;

6. conductive, intracratonic basin;

7. conductive, foreland basin/orogenic belt;

8. conductive, basement (igneous and metamorphic).

In this paper we analyse and discuss the structural setting, the heat source and the reservoir characteristics of four important geothermal fields in exploitation over decades: (i) Larderello (Italy), (ii) Mt Amiata (Italy), (iii) The Geysers (USA) and (iv) Kizildere (Turkey). We classify them as convective and intrusive play types, and we stress the similar geological features that could depict this type of play. 
The understanding of common features of convective and intrusive plays is important since they host some of the most productive geothermal fields in the world. The Larderello and Mt Amiata fields, both located in Tuscany (Italy), are two large convective geothermal systems with similarities but also many differences. Larderello is one of the few vapourdominated systems worldwide, where the first geothermal power plant was installed in 1913. The Mt Amiata geothermal area is located close to the homonymous extinct volcano (0.3-0.2 Myr) and is characterized by a liquid-dominated system. The Geysers field is located in California (USA) close to the Clear Lake volcanic field and is the most productive vapour-dominated geothermal system in the world; it has been exploited since the 1960s. The Kizildere field, located in western Turkey, is a liquid-dominated system exploited for power production since 1984, the first field in Turkey. In our analysis we include also Kizildere, which has been differently classified (IGA and IFC, 2014, and references therein), since the aim of our paper is to open a discussion and comparison between the different proposed models.

We argue that the prospective resources are hardly classified on the basis of both tectonic setting and stratigraphic features, and we propose a new classification.

\section{Structural setting}

\subsection{Larderello and Mt Amiata geothermal fields}

The geothermal fields of Larderello and Mt Amiata (southern Tuscany, Italy) are located in the inner part of the Northern Appennines, a sector of the Apennine orogenic belt developed as a consequence of the Cenozoic collision between the European (Corso-Sardinian block) and the Adria plates (Boccaletti et al., 2011). Southern Tuscany is characterized by a shallow Moho discontinuity (20-25 km depth), a reduced lithosphere thickness due to uprising asthenosphere and the delamination of crustal lithosphere (Gianelli, 2008). Many authors proposed a tectonic evolution of the Northern Apennines due to two main deformational processes: (i) a first one related to eastward-migrating compressional tectonics and (ii) a subsequent extensional tectonics migrating eastward which has been affecting the inner part of the orogenic belt since at least the early Miocene (Carmignani et al., 1994; Jolivet et al., 1998; Brogi, 2006, and reference therein). Alternative models have been proposed to describe the tectonic evolution of the inner Northern Apennines (Boccaletti et al., 1997; Bonini and Sani, 2002). These studies revealed a complex tectonic evolution during the Miocene-Pleistocene with alternating compressive and extensional tectonics events but suggest a prevalent contribution of compressive tectonics till the Pleistocene epoch, in contrast with an uninterrupted regional extensional tectonics active since at least the early Miocene as suggested by other authors. After the Pleistocene, southern Tuscany is characterized by active extensional tectonics as inferred from borehole breakout analysis (Mon- tone et al., 2012). Considering Quaternary tectonics, recent studies have suggested an important role of strike-slip faults and step-over zones controlling the magma emplacement in the inner Northern Apennines (Acocella et al., 2006) and in the Mt Amiata area (Brogi and Fabbrini, 2009). Batini et al. (1985) presented a seismological study of the Larderello area, showing an intense seismic activity of low magnitude, partially induced, that could be correlated with seismically active structures.

\subsection{The Geysers geothermal field}

The Geysers-Clear Lake geothermal field is located in northern California, between the San Andreas fault system and the Coast Range thrust (Stanley and Rodriguez al., 1995). This region belongs to the California Coastal Ranges, and its geological features are a consequence of the eastward subduction of the Farallon oceanic plate underneath the North America Plate since late Mesozoic times. The tectonic evolution of the region is quite complex. The late Mesozoic subduction system along western North America was replaced, in the Eocene period, by the Mendocino Triple Junction, which evolved in the San Andreas transform system (Stanley and Rodriguez, 1995).

The Geysers geothermal field is located between NWtrending right-lateral strike-slip faults that belong to the San Andreas fault system and exhibits normal and strike-slip faulting (Boyle et al., 2013). The analysis of seismicity (Oppenheimer, 1986; Boyle et al., 2013) indicates that most of the fault plane solutions show an extensional and strike-slip component. However, above $1 \mathrm{~km}$ depth, a reverse component is present.

\subsection{Kizildere geothermal field}

The Kizildere geothermal field is located in the Denizli and Aydin provinces of western Turkey in the easternmost part of the Büyük Menderes Graben. The western Anatolian horst-and-graben system forms the eastern boundary of the Aegean extensional system, which is one of the most active extensional regions in the world and is undergoing a N-S extension (Gürer et al., 2009, and reference therein). The west Anatolian-Aegean area underwent continental collisions which started in the Mesozoic with a collisional zone migrating southward, down to the present position of the Cyprus-Hellenic subduction zone. The differential velocity fields of plates involved in the western Anatolia-Aegean region may explain the opening of the Aegean extensional system (Doglioni et al., 2002). The Büyük Menderes Graben is about $140 \mathrm{~km}$ long and up to $14 \mathrm{~km}$ wide, and approximately trends $\mathrm{E}-\mathrm{W}$ in the Kizildere area. The main normal fault, bounding the northern margin of the graben, terminates eastward close to the Kizildere geothermal field where a horsetailing termination could facilitate the hydrothermal circulation (Faulds et al., 2009). The Büyük Menderes Graben is 
characterized by intense seismicity, mainly concentrated in the Çameli-Denizli district close to the geothermal field and dominated by low-magnitude seismic swarms (Süer et al., 2010).

\section{Heat source and thermal regime}

\subsection{Larderello and Mt Amiata geothermal fields}

The geodynamic setting and the magmatic activity produce a huge geothermal anomaly in southern Tuscany, with maximum peaks centred in the Larderello and Mt Amiata areas with values of heat flow up to $1000 \mathrm{~mW} \mathrm{~m}^{-2}$ (Baldi et al., 1994). The heat source of Larderello and Mt Amiata geothermal fields is related to shallow igneous intrusions belonging to the Tuscan Magmatic Province (TMP) according to many authors (see Gianelli, 2008, and references therein). Geophysical data (gravimetry, seismic reflection, seismology and MT) and thermal numerical modelling support the hypothesis of deep buried still molten igneous intrusions below the geothermal systems of southern Tuscany (Foley, 1992; Baldi et al., 1994; Batini et al., 1995; Bernabini et al., 1995; Gianelli et al., 1997a; Manzella et al., 1998; Mongelli et al., 1998; Gianelli, 2008). Various models relate the genesis of this magmatic activity in the inner part of the Northern Apennines to the west-dipping subduction, delamination and eastward rollback of the Adriatic lithosphere. Both the magmatism and the extensional tectonics migrated from west to east following the eastward migration of the collisional front. The Larderello intrusive bodies, cored in several deep wells, can be classified as two-mica granites ranging in composition from monzogranites to syeno-monzogranites, with ages ranging from 3.8 to $1.3 \mathrm{Myr}$ (Dini et al., 2005). Gianelli and Puxeddu (1994) summarize the geophysical evidence of the batholith beneath Larderello area: (i) a Bouguer gravity low (20-25 mGal minimum peaks), (ii) a thermal anomaly (heat flow values $>120 \mathrm{~mW} \mathrm{~m}^{-2}$ ) over an area of $600 \mathrm{~km}^{2}$, (iii) $\mathrm{P}$ wave delays (up to $1 \mathrm{~s}$ ), (iv) lack of hypocentres below 7-8 km and (v) mineralogical evidence in well SP2 (post-tectonic occurrence of corundum, sanidine and biotitetourmaline level).

Mt Amiata is a young (0.3-0.2 Myr) extinct volcano belonging to the TMP made up of trachytes, trachylatites and olivine-latites (Gianelli, 2008). The volcanic edifice hosts an important reservoir of cold and drinkable water and overlies impermeable, clayey units. As for Larderello, the hightemperature hydrothermal circulation occurs in two deepseated non-volcanic reservoir. Major bodies of intrusive rocks were never crossed by deep wells in Mt Amiata, but the heat source may be related to shallow intrusions inferred from geophysical data (Bernabini et al., 1995; Manzella et al., 1998; Finetti, 2006). This allows us to consider this geothermal play as intrusive.

\subsection{The Geysers geothermal field}

The heat source of The Geysers geothermal field corresponds to a Quaternary pluton complex $\left(>100 \mathrm{~km}^{3}\right.$ ) of batholithic dimension known as "felsite" that occurs only in the subsurface and is clearly affiliated geochemically and mineralogically with the Cobb Mountain volcanic centre of the Clear Lake volcanic field (Hulen and Nielson, 1996; Dalrymple et al., 1999). Movement of the Mendocino Triple Junction is widely believed to be the cause of northward-migrating late Tertiary and Quaternary volcanism in the California Coast Ranges (Stanley and Rodriguez, 1995). A slab window is assumed to favour asthenosphere upwelling and basic magmas emplacement that in turn have fractionated, melted or assimilated continental crust, producing felsic magma (Hulen and Nielson, 1996). According to Dalrymple et al. (1999), The Geysers plutonic complex (GPC) crystallized at $1.18 \mathrm{Ma}$ and suggests a further heat source, in addition to the intrusive mass of the GPC, to explain the observed thermal evolution of the complex. Based on deep-well data, Hulen and Nielson (1996) distinguished three type of rocks constituting the igneous body: (i) granite, (ii) microgranite porphyry and (iii) late granodiorite. The presence of batholith is supported by (i) a Bouguer gravity low $(-24 \mathrm{mGal}$ minimum peaks), (ii) a thermal anomaly with heat flow values grater than $168 \mathrm{~mW} \mathrm{~m}^{-2}$ over an area of $750 \mathrm{~km}^{2}$ and values in the range $335-500 \mathrm{~mW} \mathrm{~m}^{-2}$ over an area of $75 \mathrm{~km}^{2}$ centred on the field, (iii) $\mathrm{P}$ wave delays (up to $1 \mathrm{~s}$ ), (iv) lack of hypocentres below 5-7 km depth and (v) the occurrence of a thick aureole of biotite-tourmaline-rich hornfels around the felsite (Walters and Combs, 1989; Gianelli and Puxeddu, 1994; Nielson and Moore, 2000, and reference therein).

Both the huge vapour-dominated reservoir and the upper portion of the felsite are oriented NW-SE, sub-parallel to the right-lateral San Andreas Fault and related wrench faults. In fact, Hulen and Norton (2000) considered the emplacement of the felsite to be possibly related to pull-apart extension. The presence of a batholith or multiple silicic magma chambers at depth are supported by geophysical evidence, but a shallow intrusion cyclically replenished by new magma (at least 500000 years each) is required to keep the present-day heat flow and thermal anomaly (Erkan et al., 2005).

\subsection{Kizildere geothermal field}

Surface heat flow in western Turkey depicts wide thermal anomalies with values up to $150 \mathrm{~mW} \mathrm{~m}^{-2}$ in the Menderes Massif area (Tezcan and Turgay, 1991). The exploration activities carried out in the Kizildere area were not able to clearly identify a shallow intrusion or a magmatic chamber as a possible heat source of the system.

Faulds et al. (2009) compared the western Turkey region to the western Great Basin undergoing significant extension and relatively sparse volcanism and excluded a magmatic heat source at upper crustal levels for the geothermal sys- 
tems in the area. The primary control of structural features accommodating deep hydrothermal circulation is therefore suggested.

On the other hand, geochemical and isotopic analyses of C, S and B (Özgür, 2002; Simsek, 2003; Özgür and Karamenderesi, 2015) support the hypothesis of relatively shallow and recent magmatic intrusion. On the basis of helium isotopic data, Güleç and Hilton (2006) suggest the occurrence of plutonic activity underneath the Büyük Menderes Graben. This is consistent with the fact that during the late Miocene to Quaternary an oceanic-island basalt (OIB)-type volcanism occurs during the recent extensional phase in the Anatolian-Aegean region (Agostini et al., 2007). The most recent Quaternary volcanic products are found in the Kula region located about $65 \mathrm{~km}$ NW of Kizildere field.

The $\mathrm{C}^{13}$ analysis indicates a substantial contribution of magmatic $\mathrm{CO}_{2}$, although $\mathrm{CO}_{2}$ mainly derives from decarbonatization processes (Simsek, 2003). By comparison, similar processes occurred at Larderello and Mt Amiata, where $\mathrm{CO}_{2}$ is in part produced by high-temperature decarbonatization reaction of sediments under thermo-metamorphic conditions (Gianelli and Calore, 1996; Gianelli et al., 1997b; Orlando et al., 2010).

Considering that young intrusion is inferred in Kizildere and remembering that intrusive rocks below Larderello and The Geysers were disputed and not clearly proved until these rocks were reached by deep drilling, we include Kizildere in the discussion of intrusive plays.

\section{Reservoir characteristics}

\subsection{Larderello and Mt Amiata geothermal fields}

There are differences and similarities between the Larderello and Mt Amiata geothermal reservoirs. Both areas host two reservoirs, the shallow being hosted in sedimentary units and the deep in crystalline rocks. At Larderello superheated steam is present at depths over $3.5 \mathrm{~km}$ and with temperatures exceeding $350{ }^{\circ} \mathrm{C}$, whereas the deep reservoir of the Mt Amiata geothermal fields is in a two-phase (liquid + vapour mixture) state with temperatures of $300-350^{\circ} \mathrm{C}$ (Barelli et al., 2010). In the upper levels (shallow reservoir), the Larderello reservoir consists of several rock types: sandstone; marls; radiolarites; and, more commonly, Mesozoic micritic limestone and anhydrite dolostone. The deep reservoir consists of phyllite, micaschist, skarn, hornfelses and granite. Similar rocks form the reservoir of the Mt Amiata geothermal field: Mesozoic limestone and anhydrite dolostone (shallow reservoir), and phyllite, quartzite and dolomitic marbles (deep reservoir) (Pandeli et al., 1988). Strong reflectors in the metamorphic complexes have been explained with rock fracturing and the presence of fluids (Batini et al., 1983; Cameli et al., 1995). Gianelli and Bertini (1993) report the occurrence of a hydrothermal breccia at $1090 \mathrm{~m}$ depth and suggest that natural hydraulic fracturing could have occurred within the sys- tem. Hydraulic fracturing may also be a present-day mechanism of rock fracturing at Larderello. Also at Mt Amiata, in the deep reservoir, the occurrence of hydrothermal breccias (Ruggieri et al., 2004) leads us to assume a similar process of permeability enhancement. Coupled with this process, it is clear that faults and densely fractured zones play a fundamental role in the permeability of the reservoir, considering that primary permeability is extremely low.

Barelli et al. (2010) highlight that the shallow and deep reservoirs of the Mt Amiata system are in piezometric equilibrium as pointed out by the hydrostatic pressure distribution.

Thermal springs and diffuse gas discharge are abundant in both Larderello and Amiata geothermal fields and surrounding areas, with fierce manifestations in Larderello (Duchi et al., 1986; Minissale et al., 1991, 1997; Frondini et al., 2009).

\subsection{The Geysers geothermal field}

At The Geysers the geothermal fluids are hosted principally by highly deformed late-Mesozoic-age subduction-trenchrelated metasedimentary and meta-igneous rocks of the Franciscan complex. The system is disrupted by high-angle, generally northwest-trending faults related to the still-active San Andreas Fault and low- to moderate-angle thrust faults. The Franciscan rocks at The Geysers are intruded by a northwesttrending Plio-Pleistocene multi-phase felsic pluton, which actually hosts a portion of the steam reservoir and underwent further mineral recrystallization due to the intrusion and related fluids. The configurations of the felsite and reservoir coincide, strongly suggesting that the intrusion critically influenced steam-field evolution (Hulen and Nielson, 1993). The two reservoirs (shallow and deeper "high-temperature zone") produce steam at temperatures in the range $235-342{ }^{\circ} \mathrm{C}$ at depth of approximately $500-2500 \mathrm{~m}$ b.g.l., and the permeability is mainly related to rock fractures. Recent experimental redrilling and deepening of an abandoned well were able to significantly increase the flow rate of a low-permeability level at $3350 \mathrm{~m}$ depth and $400{ }^{\circ} \mathrm{C}$ temperature, and, practically, create an enhanced geothermal system (EGS) demonstration project into the high-temperature zone (Garcia et al., 2012)

Geothermal surface manifestation are widely diffused counting several thermal springs in the surrounding area (Donnelly-Nolan et al., 1993).

\subsection{Kizildere geothermal field}

The Kizildere field is characterized by three different liquiddominated reservoirs hosted in fractured sedimentary and metamorphic rocks. The first well (KD1) was completed in 1968, reaching $198^{\circ} \mathrm{C}$ at $540 \mathrm{mb}$.g.l. in the first reservoir, constituted mainly of Neogene limestone and marls (Kindap et al., 2010). The second geothermal reservoir is hosted in Paleozoic metamorphic rocks (marble and quartzite schists) 
with a maximum temperature of $212{ }^{\circ} \mathrm{C}$. A third reservoir was discovered in 1998, after the completion of the deep well R1, initially designed for re-injection and converted into a production well. The well $\mathrm{R} 1$ reached a temperature of $242^{\circ} \mathrm{C}$ at $2261 \mathrm{~m}$ b.g.l., as presumed by previous geochemical studies (Serpen and Ugur, 1998, and reference therein). Serpen et al. (2000) do not consider the lithological differences enough to distinguish first and second reservoir but suggested only a single fractured reservoir, independent of stratigraphic features, located at 300-1000 m depth with an average temperature of $205^{\circ} \mathrm{C}$. The hydrothermal circulation in the reservoir is related to structural permeability, and primary porosity of rocks is low. Geothermal surface manifestation are widely diffused in the Kizildere field, counting several thermal springs in the surrounding area, with temperatures ranging from 37 to $88^{\circ} \mathrm{C}$ (Özgür, 2002).

\section{Discussion}

In our opinion a worldwide-accepted temperature-based classification of geothermal resources is needed, because it provides a quantitative evaluation of power production. On the other hand, in agreement with the definition of geothermal play of Moeck (2014), in the first stage of exploration it is useful to take into account a catalogue of plays based on geological features. But we argue with the following question: are geological features clear enough for characterizing favourable conditions for geothermal resources?

The comparison of the main geological conditions among the Larderello and Mt Amiata (Italy), The Geysers (USA) and Kizildere (Turkey) geothermal fields led us to identify common features that may characterize the convective and intrusive play. The most important common feature of this type of play is the effectiveness of the heat source represented by shallow plutonic intrusions, although nowadays for Mt Amiata and Kizildere fields the magmatic contribution is only inferred, as it was inferred in Larderello and The Geysers at the beginning. This is a crucial point, and the term intrusive for a play is not so immediate to apply. For example, different models have been also proposed for Kizildere with the magmatic activity the main matter of debate, as in Larderello and The Geysers before drilling and coring granites and felsite. Another example is that recent acidic intrusions are considered to be the heat source of Larderello and Mt Amiata geothermal systems (Bertini et al., 2006; Gianelli, 2008), whereas in the conceptual model of the Larderello geothermal area of Brogi et al. (2003, and references therein) the geothermal area is located in a "basin and range"-like structure, the magmatic contribution as heat source being minimized and depicting an overall scenario of a fault-controlled system.

The efficacy of the heat source is a leading issue. In fact, with regard to the Italian and American fields the available information nowadays endorses the effectiveness of buried intrusion older than $1 \mathrm{Myr}$. Mathematical models exclude the possibility that intrusions of any reasonable, even large, size can supply enough heat and are able to feed large geothermal systems for more than $1 \mathrm{Myr}$ (Norton and Knight, 1977; Calore et al. 1981; Cathless and Erendi, 1997). A continuous magma, and therefore heat, feeding is therefore necessary to maintain a geothermal system of the size of Larderello or The Geyser. In our opinion, the term "intrusive" should be accompanied by the term "Young". We can define young as an intrusion at least coeval, or younger than the last tectonic phase affecting the geothermal area, and if isotopic dating is available it should be younger than approximately $1 \mathrm{Myr}$.

The age of the magmatism is used also for the catalogue of geothermal play proposed by IGA and IFC (2014), which, however, lacks a clear distinction of volcanic and intrusive plays. In our opinion a system fed by young intrusions with the geothermal reservoir hosted in the associated volcanites has different features with respect to a "convective, intrusive" play, with the reservoir hosted in sedimentary and crystalline units. The geothermal plays characterized by intrusions approximately older than $1 \mathrm{Myr}$ and without evidence of melt or partial melting in the upper crust could be included into a "amagmatic play", to be eventually sub-classified. Geochemical data on surface manifestations should be considered to support the cataloguing activities because they provide useful information about the hypothesis of magmatic contribution, helping in discriminating the intrusive and amagmatic systems.

Of course, large or composite batholiths are better heat sources than small dikes or laccoliths, which cannot induce thermal anomaly for a long period of time. The volume of the intrusion, however, is not a good discriminating parameter, because during the exploration it is difficult to define its size. Thus, further distinguishing the intrusive plays on the basis of the size of the intrusion is in our opinion not of practical use.

Another important issue is the convective heat transfer that implies the circulation of a thermovector fluid. This condition distinguishes the conventional system exploitable by current technologies from the conductive unconventional geothermal systems that require engineering stimulation. The four geothermal systems are classified as convective since they show a wide and effective hydrothermal circulation, even complex, considering the presence of more than one reservoir for each field. In our analysis we could count on geophysical data and well logs for fields in operation. Considering an initial stage of exploration for a play, without geophysical data, it is difficult to assess the regime of heat transfer at depth. A preliminary indication could be provided by the number and type of geothermal manifestations in the surrounding areas. Surface manifestations (e.g. hot springs and gas discharge) are common in the four fields of interest, disregarding the fluid phase in the reservoir (steam-dominated in Larderello and The Geysers, and liquid-dominated in Amiata and Kizildere). In the considered cases, the low-permeability layer acting as a cap rock is a low-permeability sedimentary 
or crystalline unit, and the abundance and distribution of natural manifestations, as well as the hydraulic head of steam or brine, are strictly related to the depth of the reservoir and the faults and fractures regime.

Attempts at evaluating the steam fraction in a geothermal reservoir have been proposed by D'Amore and Truesdell (1979), but its application before drilling and during the geochemical survey of natural manifestation is problematic. In any case the presence of steam phase is not an indication for intrusive or fault-controlled geothermal systems. For example Mt Amiata is an intrusive geothermal system with liquid-dominated reservoirs.

The comparison of these fields drove us to exclude lithological and stratigraphic conditions as key parameters to classify the plays. A geothermal reservoir can be hosted in various typologies of sedimentary and crystalline rocks. What really matters is the rock permeability.

What makes things even more complex is the geodynamic and structural setting, which may spatially vary in stress regime (from compressive to extensional or strike slip) and in time (polyphasic tectonic). In areas rich in data such as those we analysed the tectonic evolution is still under debate in the scientific community. We have shown that Larderello and Mt Amiata are located in the inner sector of an active orogenic belt that has undergone extensional tectonics since the Miocene or Pleistocene (non-univocal consensus about timing), and some authors have suggested the importance of recent strike-slip faults during the emplacement of plutons that represent the heat source.

The main elements in common in the four fields which we used for the classification are the hydrothermal circulation and the known or inferred plutonic heat source, respectively identifying the convective and intrusive terms. We observe that there are two other common parameters in the four areas: (i) relevant seismic activity and (ii) high heat flow. It is known that geothermal fields are common in tectonically active areas and earthquake swarms could be associated with areas of recent volcanic or geothermal activity (Sibson, 1996). The heat flow values depict huge thermal anomalies in the surrounding areas of the Larderello, Mt Amiata, The Geysers and Kizildere fields, with maximum values centred on the field in exploitation.

\section{Conclusions}

We compared the main geological features of the Larderello, Mt Amiata, The Geysers and Kizildere geothermal fields in order to describe the common elements that could be useful for the classification of geothermal plays based on the terminology proposed for the IGA workshop held in Essen, Germany (IGA, 2013). We classified these fields as convective and intrusive plays. The first term would indicate the presence of a reservoir suitable for economic exploitation with current technologies without engineering stimulation. The term intrusive is correlated with the plutonic heat source that feeds wide and highly productive geothermal systems. We do not adhere to the proposal to split this play into different kinds depending on the tectonic setting. Considering that a play should be defined in an unambiguous way, and should help in classifying resources and planning exploration decisions, we conclude that recognized resources, such as those we analysed, and even more so the prospective resources, can hardly be classified on the basis of tectonic setting. We explained that geodynamic and structural setting are still debated in such well-known fields, and a tectonics-based classification of geothermal plays could not simplify the exploration planning. The structural survey remains a milestone in a geothermal exploration project to understand tectonics evolution and to assess the faults and fractures systems that control hydrothermal circulation.

With regard to the classification of geothermal plays we suggest simplifying the classification of the convective plays, distinguishing volcanic, young intrusive and amagmatic. Our classification reduces the emphasis on the tectonic settings, which can be subjective and therefore lead to ambiguous conceptual models. Besides highlighting the importance of geochemical data for inferring magmatic heat source, we identify two more features that are common in the four fields: (i) they are seismically active, and (ii) they show high heat flow values and wide thermal anomalies. These features, more than structural and tectonic features, might be used for a sub-classification.

Acknowledgements. The authors would like to thank the anonymous reviewers for their valuable comments and suggestions, which greatly contributed to improve the final version of the paper. A special acknowledgement also goes to Samuele Agostini for the useful discussion on the subject of this study.

Edited by: I. S. Moeck

Reviewed by: two anonymous referees

\section{References}

Acocella, V. and Funiciello, R.: Transverse systems along the extensional Tyrrhenian margin of central Italy and their influence on volcanism, Tectonics, 25, 1-24, doi:10.1029/2005TC001845, 2006.

Agostini, S., Doglioni, C., Innocenti, F., Manetti, P., Tonarini, S., and Savaşçin, M. Y.: The transition from subduction-related to intraplate Neogene magmatism in the Western Anatolia and Aegean area, in: Cenozoic Volcanism in the Mediterranean Area, edited by: Beccaluva, L., Bianchini, G., and Wilson, M., Geol. S. Am. S., 418, 1-15, doi:10.1130/2007.2418(01), 2007.

Allen, P. A and Allen, J. R.: The Petroleum Play, in: Basin AnalysisPrinciples and Applications, Blackwell Science Ltd., Oxford, UK, 405-494, 2005.

Baldi, P., Bellani, S., Ceccarelli, A., Fiordelisi, A., Squarci, P., and Taffi, L.: Correlazioni tra le anomalie termiche ed altri elementi geofisici e strutturali della Toscana meridionale, Studi Geologici Camerti, Volume Speciale 1994-1, 139-149, 1994. 
Barelli, A., Ceccarelli, A., Dini, I., Fiordelisi, A., Giorgi, N., Lovari, F., and Romagnoli, P.: A Review of the Mt. Amiata Geothermal System (Italy), Proceedings of the World Geothermal Congress, Bali, Indonesia, 25-29 April 2010, 1-6, 2010.

Batini, F., Bertini, G., Gianelli,G., Pandeli, E., and Puxeddu, M.: Deep structure of the Larderello field: contribution from recent geophysical and geological data, Mem. Soc. Geol. It., 25, 219235, 1983.

Batini, F., Console, R., and Luongo, G.: Seismological study of Larderello-Travale geothermal area, Geothermics, 14, 255-272, 1985.

Batini, F., Fiordelisi, A., Graziano, F., and Toksöz, M.N.: Earthquake Tomography in the Larderello Geothermal Area, Proceedings of the World Geothermal Congress, Florence, Italy, 18-31 May 1995, 1995-2, 817-820, 1995.

Bernabini, M., Bertini, G., Cameli, G. M., Dini, I., Orlando, L.: Gravity Interpretation of Mt. Amiata Geothermal Area (Central Italy), Proceedings of the World Geothermal Congress, Florence, Italy, 18-31 May 1995, 1995-2, 817-820, 1995.

Bertini, G., Casini, M.. Gianelli, G., and Pandeli E.: Geological structure of a long-living geothermal system, Larderello, Italy, Terra Nova, 18, 163-169. 2006.

Boccaletti, M., Gianelli, G., and Sani, F.: Tectonic regime, granite emplacement and crustal structure in the inner zone of the Northern Apennines (Tuscany, Italy): A new hypothesis, Tectonophysics, 270, 127-143, doi:10.1016/S0040-1951(96)00177-1, 1997.

Boccaletti, M., Corti, G., and Martelli, L.: Recent and active tectonics of the external zone of the Northern Apennines (Italy), Int. J. Earth Sci., 100, 1331-1348, doi:10.1007/s00531-010-0545-y, 2011.

Bonini, M. and Sani, F.: Extension and compression in the Northern Apennines (Italy) hinterland: Evidence from the late MiocenePliocene Siena-Radicofani Basin and relations with basement structures, Tectonics, 21, 1-33, doi:10.1029/2001TC900024, 2002.

Boyle, K. and Zoback, M.: Stress and fracture orientation in the northwest Geysers geothermal field, Proceedings of ThirtyEighth Workshop on Geothermal Reservoir Engineering, Stanford University, Stanford, CA, USA, 11-13 February 2013, 7 pp., 2013.

Brogi, A., Lazzarotto, A., Liotta, D., and Ranalli, G.: Extensional shear zones as imaged by reflection seismic lines: the Larderello geothermal field (Central Italy), Tectonophysics, 363, 127-139. 2003.

Brogi, A.: Neogene extension in the Northern Apennines (Italy): insights from the southern part of the Mt. Amiata geothermal area, Geodin. Acta, 19/1, 1-9, doi:10.3166/ga.19.33-50, 2006.

Brogi, A. and Fabbrini, L.: Extensional and strike-slip tectonics across the Monte Amiata-Monte Cetona transect (Northern Apennines, Italy) and seismotectonic implications, Tectonophysics, 476, 195-209, doi:10.1016/j.tecto.2009.02.020, 2009.

Calore, C., Celati, R., Gianelli, G., Norton, D., and Squarci, P.: Studi sull'origine del sistema geotermico di Larderello. Atti II Seminario Informativo del Sottoprogetto Energia Geotermica, Progetto Finalizzato Energetica, Roma, Italy, 16-19 June 1981, PEG Editrice, 218-225, 1981.

Cameli, G. M., Batini, F., Dini, I., Lee, J. M., Gibson R. L., and Toksoz M. N.: Seismic delineation of a geothermal reservoir in the
Monteverdi area from VSP data, Proceedings of World Geothermal Congress, Florence, Italy, 18-31 May 1995, 821-826, 1995.

Carmignani, L., Decandia, F. A., Fantozzi, P. L., Lazzarotto, A., Liotta, D., and Meccheri, M.: Tertiary extensional tectonics in Tuscany (Northern Apennines, Italy), Tectonophysics, 238, 295 315, 1994.

Cathless, L. M. and Erendi, A. H. J.: How long can a hydrothermal system be sustained by a single event?, Econ. Geol., 77, 10711084, 1997.

D'Amore, F. and Truesdell, A. H.: Models for steam chemistry at Larderello and The Geyser, Proc. 5th Workshop on Geothermal Reservoir Engineering, 12-14 December 1979, 283-297, Stanford, CA, USA, 1979.

Dalrymple, G. B., Grove, M., Lovera, O. M., Harrison, T. M., Hulen, J. B., and Lanphere, M. A.: Age and thermal history of the Geysers plutonic complex (felsite unit), Geysers geothermal field, California: a ${ }^{40} \mathrm{Ar} /{ }^{39} \mathrm{Ar}$ and U-Pb study, Earth Planet. Sc. Lett., 173, 285-298, 1999.

Dini, A., Gianelli, G., Puxeddu, M., and Ruggieri, G.: Origin and evolution of Pliocene-Pleistocene granites from the Larderello geothermal field (Tuscan Magmatic Province, Italy), Lithos, 81, 1-31, doi:10.1016/j.lithos.2004.09.002, 2005.

Doglioni, C., Agostini, S., Crespi, M, Innocenti, F., Manetti, P., Riguzzi, F., and Savasçin, Y.: On the extension in western Anatolia and the Aegean sea, in: Reconstruction of the evolution of the Alpine-Himalayan Orogen, edited by: Rosenbaum, G. and Lister, G. S., Journal of the Virtual Explorer, 8, 161-176, 2002.

Donnelly-Nolan, J. M., Burns, M. G., Goff, F. E., Peters, E. K., and Thompson, J. M.: The Geysers-Clear Lake area, California: thermal waters, mineralization, volcanism, and geothermal potential, Econ. Geol., 88, 301-316, doi:10.2113/gsecongeo.88.2.301, 1993.

Duchi, V., Minissale, A., and Rossi, R.: Chemistry of thermal springs in the Larderello-Travale geothermal region, southern Tuscany, Italy, Appl. Geochem., 1, 659-667, 1986.

Erkan, K., Blackwell D. D., and Leidig M. M.: Crustal thermal regime at The Geysesrs/Clear Lake Area, California, Proceedings World Geothermal Congress, Antalaya, Turkey, 24-29 April 2005, 1-9, 2005.

Faulds, J. E., Bouchot, V., Moeck, I., and Oguz, K.: Structural Controls on Geothermal Systems in Western Turkey: A Preliminary Report, Geoth. Res. T., 33, 375-381, 2009.

Finetti, I. R.: Basic regional crustal setting and superimposed local pluton-intrusion-related tectonics in the Larderello-Mt. Amiata geothermal province, from integrated CROP seismic data, Boll. Soc. Geol. Ital., 125, 117-146, 2006.

Foley, J. E., Toksoz, M. N., and Batini, F.: Inversion of teleseismic traveltime residuals for velocity structure in the Larderello geothermal system, Italy, Geophys. Res. Lett., 19, 5-8, 1992.

Frondini, F., Caliro, S., Cardellini, C., Chiodini, G., and Morgantini, N.: Carbon dioxide degassing and thermal energy release in the Monte Amiata volcanic-geothermal area (Italy), Appl. Geochem., 24, 860-875, 2009.

Garcia, J., Walters, M., Beall, J., Hartline, C., Pingol, A., Pistone, S., and Wright, M.: Overview of The Northwest Geysers EGS Demonstration Project, Proceedings of Thirty-Seventh Workshop on Geothermal Reservoir Engineering, Stanford, CA, USA, 30 January-1 February 2012, 11 pp., 2012. 
Garg, S. K., Haizlip, J., Bloomfield, K. K., Kindap, A., Haklidir, F. S. T., and Guney, A.: A Numerical Model of the Kizildere Geothermal Field, Turkey, Proceedings of World Geothermal Congress, 19-25 April 2015, Melbourne, Australia, 1-15, 2015.

Gianelli, G.: A comparative analysis of the geothermal fields of Larderello and Mt. Amiata, Italy, in: Geothermal energy research trends, edited by: Ueckermann, H. I., Nova Science Publishers, New York, USA, 59-85, 2008.

Gianelli, G. and Bertini, G.: Natural hydraulic fracturing in the Larderello geothermal field: evidence from well MV5A, Boll. Soc. Geol. Ital., 112, 507-512, 1993.

Gianelli, G. and Puxeddu, M.: Geological comparison between Larderello and The Geysers geothermal fields, Mem. Soc. Geol. It., 48, 715-717, 1994.

Gianelli, G. and Calore, C.: Models for the origin of carbon dioxide in the Larderello geothermal field, Boll. Soc. Geol. Ital., 115, 7584. 1996

Gianelli, G., Manzella, A., and Puxeddu, M.: Crustal models of the geothermal areas of southern Tuscany (Italy), Tectonophysics, 281, 221-239, 1997a.

Gianelli, G., Ruggieri, G., and Mussi, M.: Isotopic and fluid inclusion study of hydrothermal and metamorphic carbonates in the Larderello geothermal field and surrounding areas, Italy, Geothermics, 26, 393-417. 1997b

Güleç, N. and Hilton, D. R.: Helium and heat distribution in Western Anatolia, Turkey. Relationship to active extension and volcanism, in: Postcollisional tectonics and magmatism in the Mediterranean region and Asia, edited by: Dilek, Y. and Pavlides, S., Geol. S. Am. S., 409, 305-319, doi:10.1130/2006.2409(16), 2006.

Gürer, Ö.F., Sarica-Filoreau, N., Özburan, M., Sangu, E., and Dogan, B.: Progressive development of the Büyük Menderes Graben based on new data, western Turkey, Geol. Mag., 146, 652-673, doi:10.1017/S0016756809006359, 2009.

Hulen, J. B. and Nielson, L. D.: Interim Report on Geology of The Geysers Felsite, Northwestern California, Geoth. Res. T., 17, 249-258, 1993.

Hulen, J. B. and Nielson, L. D.: The Geysers felsite, Geoth. Res. T., 20, 295-306, 1996.

Hulen, J. B. and Norton, D. L.: Wrench-fault tectonics and emplacement of The Geysers Felsite, Geoth. Res. T., 24, 289-298, 2000.

IGA: Workshop: Developing Best Practice for Geothermal Exploration and Resource/Reserve Classification, 14 November 2013, Essen, Germany, available at: http://www.geothermal-energy. org/reserves_and_resources/workshop_essen.html (last access: September 2015), 2013.

IGA and IFC: Best practices guide for geothermal exploration, IGA Service GmbH, 2014.

Jolivet, L., Faccenna, C., Goffé, B., Mattei, M., Rossetti, F., Brunet, C., Storti, F., Funiciello, R., Cadet, J.P., d'Agostino, N., and Parra, T.: Midcrustal shear zones in postorogenic extension: Example from the northern Tyrrhenian Sea, J. Geophys. Res, 103, 12123-12160, 1998.

Kindap, A., Kaya, T., Haklıdır, F. S. T., and Bükülmez, A. A.: Privatization of Kizildere Geothermal Power Plant and New Approaches for Field and Plant, Proceedings of the World Geothermal Congress, Bali, Indonesia, 25-29 April 2010, 1-4, 2010.
Manzella, A., Ruggieri, G., Gianelli, G., and Puxeddu, M.: PlutonicGeothermal systems of southern Tuscany: a review of the crustal models, Mem. Soc. Geol. It., 52, 283-294, 1998.

Minissale A.: The Larderello geothermal field: a review, Earth-Sci. Rev., 31, 133-151, 1991.

Minissale, A., Magro, G., Vaselli, O., Verrucchi, C., and Perticone, I.: Geochemistry of water and gas discharges from the Mt. Amiata silicic complex and surrounding areas (central Italy), J. Volcanol. Geoth. Res., 79, 223-251, 1997.

Moeck, I. S.: Catalog of geothermal play types based on geologic controls, Renew. Sust. Energ. Rev., 37, 867-882, doi:10.1016/j.rser.2014.05.032, 2014.

Mongelli, F., Palumbo, F., Puxeddu, M., Villa, I. M., and Zito, G.: Interpretation of the geothermal anomaly of Larderello, Italy, Mem. Soc. Geol. It., 52, 305-318, 1998.

Montone P., Mariucci, M. T., and Pierdominici, S.: The Italian present-day stress map, Geophys. J. Int., 189, 705-716, doi:10.1111/j.1365-246X.2012.05391.x, 2012.

Muffler, L. J. P: Assessment of geothermal resources of the United States - 1978, USGS, Circular 790, 163 pp., 1979.

Nielson, D. and Moore, J. N.: The Deeper Parts of The Geysers Thermal System-Implications for Heat Recovery, Geoth. Res. T., 24, 299-302, 2000.

Norton, D and Knight, J.: Transport phenomena in hydrothermal systems: cooling plutons, Am. J. Sci., 277, 937-981, 1977.

Oppenheimer, D. H.: Extensional tectonics at The Geysers geothermal area, J. Geophys. Res., 91, 11463-11476, 1986.

Orlando, A., Conte, A. M., Borrini, D., Perinelli, C., Gianelli, G., and Tassi, F.: Experimental investigation of $\mathrm{CO}_{2}$-rich fluids production in a geothermal area: The Mt. Amiata (Tuscany, Italy) case study, Chem. Geol., 274, 177-186, 2010.

Özgür, N.: Geochemical Signature of the Kizildere Geothermal Field, Western Anatolia, Turkey, Int. Geol. Rev., 44, 153-163, 2002.

Özgür, N. and Karamenderesi, İ. H.: An Update of the Geothermal Potential in the Continental Rift Zone of the Büyük Menderes, Western Anatolia, Turkey, Proceedings, Fortieth Workshop on Geothermal Reservoir Engineering Stanford University, 26-28 January 2015, Stanford, CA, USA, sgp-tr-204, 1-7, 2015.

Pandeli, E., Puxeddu, M., Gianelli, G., Bertini, G., and Castellucci, P.: Paleozoic sequences crossed by deep drillings in the Monte Amiata geothermal region (Italy), Boll. Soc. Geol. Ital., 107, 593-606, 1988.

Ruggieri G., Giolito C., Gianelli G., Manzella A., and Boiron M. C.: Application of fluid inclusions to the study of Bagnore geothermal field (Tuscany, Italy), Geothermics, 33, 675-692, 2004.

Serpen, U. and Ugur, Z.: Reassessment of Geochemistry of the Kizildere Geothermal Field, Geoth. Res. T., 22, 135-140, 1998.

Serpen, U. and Satman, A., Reassessment of the Kizildere geothermal reservoir, Proceedings of World Geothermal Congress, 28 May-10 June 2000, Beppu-Morioka, Japan, 2869-2874, 2000.

Sibson, R. H.: Structural permeability of fluid-driven fault-fracture meshes, J. Struct. Geol., 18, 1031-1042, 1996.

Simsek, S., Hydrogeological and isotopic survey of geothermal fields in the Buyuk Menderes graben, Turkey, Geothermics, 32, 669-678, doi:10.1016/S0375-6505(03)00072-5, 2003.

Stanley, W. D. and Rodriguez, B. D.: A Revised Tectonic Model for The Geysers- Clear Lake Geothermal Region, California, Pro- 
ceedings of the World Geothermal Congress, Florence, Italy, 1831 May 1995, 1193-1198, 1995.

Süer, S., Wiersberg, T., Güleç, N., Erzinger, J., and Parlaktuna, M.: Geochemical Monitoring of the Seismic Activities and Noble Gas Characterization of the Geothermal Fields along the Eastern Segment of the Büyük Menderes Graben, Proceedings of World Geothermal Congress, 25-29 April 2010, Bali, Indonesia, 1-8, 2010.
Tezcan, A. K. and Turgay, M. I.: Heat flow and temperature distribution in Turkey, in: Geothermal Atlas of Europe, edited by: Hurtig, E., Cermak, V., Haenal, R., and Zui, V., 84-85, 1991.

Walters, M. and Combs, J.: Heat Flow Regime in The Geysers-Clear Lake Area of Northern California, USA, Geoth. Res. T., 13, 491$502,1989$. 